\title{
Biological Responses of Sheep treated with Endotoxin-Contaminated Superoxide Dismutase and Endotoxin Preparations
}

\author{
By Chahna R. Yagoda, Ann-Christin Bylund-Fellenius, Niklas Adner and Hans Kindahl \\ Swedish University of Agricultural Sciences, Department of Obstetrics and Gynaecology, \\ and Pharmacia LEO Therapeutics AB, Uppsala, Sweden.
}

Yagoda, C. R., A.-C. Bylund-Fellenius, N. Adner and H. Kindahl: Biological responses of sheep treated with endotoxin-contaminated superoxide dismutase and endotoxin preparations. Acta vet. scand. 1990, 31, 207-217. - The purpose of this study was to evaluate the biological response of sheep to different doses of endotoxin and endotoxin-contaminated enzyme preparations. The enzyme used in this experiment was superoxide dismutase (SOD), as it is currently being used in many different experiments and because several preparations were found to be heavily contaminated with endotoxin.

A group of ewes were injected intravenously with a variety of different treatments. Peripheral blood was used to determine the total number of leukocytes, a differential cell count to find out the numbers of polymorphonucleocytes (PMN) and monocytes $(\mathrm{M})$, and to measure the concentration of 15 -ketodihydro-PGF $2 \alpha$. In addition, rectal temperature was recorded. Treatments included saline (control), Pharmacia-Chiron's Cu/Zn-SOD (r-hSOD, $8 \mathrm{mg} / \mathrm{kg}$ ), Sigma's bovine SOD (bSOD, $8 \mathrm{mg} / \mathrm{kg})$, Grünenthal's bSOD $(8 \mathrm{mg} / \mathrm{kg})$, various doses of Salmonella typhimurium endotoxin $(1000,200,100,50,20,10,5$, and $1 \mathrm{ng} / \mathrm{kg})$, and a mixture of endotoxin $(200 \mathrm{ng} / \mathrm{kg})$ plus $\mathrm{r}-\mathrm{hSOD}(8 \mathrm{mg} / \mathrm{kg})$.

Results indicate that sheep react to endotoxin-contaminated SOD preparations with an endotoxemia which is similar to that seen in animals receiving endotoxin alone. This endotoxemia includes, among other things, a rise in rectal temperature, a peak in the $\mathrm{PGF}_{2 \alpha}$ metabolite, and an increased PMN/M ratio.

Endotoxin administered at doses of 50 to $200 \mathrm{ng} / \mathrm{kg}$ also caused the expected signs of endotoxemia. At $1000 \mathrm{ng} / \mathrm{kg}$ endotoxin actually led to a decreased rectal temperature. This may be due to a type of endotoxemic shock, resulting in a decrease in peripheral blood circulation.

Low doses of endotoxin $(10,5$, and $1 \mathrm{ng} / \mathrm{kg})$ caused a leukocytosis via increases in $\mathrm{PMN}$; no greater changes in rectal temperature or the $\mathrm{PGF}_{2 \alpha}$ metabolite were noted.

The combination of $\mathrm{r}-\mathrm{hSOD}$ with $200 \mathrm{ng} / \mathrm{kg}$ of endotoxin caused an endotoxemia similar to that caused by $200 \mathrm{ng} / \mathrm{kg}$ of endotoxin alone.

In conclusion, if an endotoxin-contaminated SOD-preparation was used to study the efficacy of SOD, there would be a serious risk of interaction by the endotoxins. In such a case it would be impossible to distinguish the effects of the endotoxin from those of the preparation itself. It is therefore important that researchers are alert to the problem of endotoxin contamination.

prostaglandin; leukocytes.

\section{Introduction}

Endotoxins, found in the cell wall of Gramnegative bacteria, have been shown to me- diate many pathological reactions in the mammalian body. Endotoxins can, for example, cause fever, chills, and headache in 
humans when administered at doses less than or equal to $3 \mathrm{ng} / \mathrm{kg}$ body weight (Elin et al. 1981). Endotoxins can cause the adult respiratory distress syndrome, lead to a lifethreatening fall in blood pressure via stimulation of the kallekrein-kinin system (Morrison \& Raziuddin 1982), or affect reproductive function through activation of the arachidonic acid cascade (Kindahl et al. 1989). The severity and range of effects that endotoxin has, however, are very dose dependent. This means that an animal receiving a very low dose of endotoxin may not show any of the clinical signs of endotoxemia, but can still have subclinical changes such as leukopenia, mild hypocalcemia, and decreases in plasma levels of zinc and iron (Luthman et al. 1988).

Endotoxins exist almost everywhere in the environment. One may find them for example in food, especially in silage (Lindgren et al. 1988), dust, water, chemicals, and even in certain drugs, medical devices (Kure et al. 1982, Asplund Peiró et al. 1989) and biological preparations (Bito 1977, Zuckerman et al. 1979, Yagoda et al. 1990). Contamination of biological preparations are of special concern, because this contamination can produce erratic results, or even worse, produce an effect that the preparation is later credited with. For example, Gordon et al. (1987) found that it was the contaminating endotoxin and not catalase itself which produced protective effects in a model of induced airway edema in guinea pigs. Endotoxins have also been shown to induce an increase in the catalase activity in the rat heart and thus exert a protective effect against ischemia-reperfusion injuries (Brown et al. 1989). Thus, contamination with endotoxins in biological preparations is a problem that deserves further attention. This problem has earlier been addressed in a study in which rabbits were used as the ani- mal model (Yagoda et al. 1990). The purpose of this study is to evaluate the biological response of sheep to different doses of endotoxin and endotoxin-contaminated protein preparations. The preparation which we used in this study was superoxide dismutase (SOD), as it is currently being used in many pharmacological studies and because several commercial preparations were found to be heavily contaminated with endotoxin.

\section{Materials and methods}

A group of ewes weighing an average of 43 $(37-66) \mathrm{kg}$ were used in 6 successive trials spaced at approximately 2 month intervals. The animals were divided into groups as described in Table 1. Attempts were made to avoid repetition of the same treatment to the same animal to minimize any possible effects of tolerance. All animals were injected intravenously with their respective treatment shortly after the time zero blood collection was made. The control animals were injected with $5 \mathrm{ml}$ of saline which contained $<0.12$ endotoxin units $(\mathrm{EU}) / \mathrm{ml}$, as determined by the Limulus Amoebocyte Lysate (LAL) test (see Friberger 1985). Calculated as a dose per kilogram body weight this is equal to $<0.01 \mathrm{EU} / \mathrm{kg}$. Animals treated with "endotoxin-free" (0.16 EU/mg protein) recombinant human $\mathrm{Cu} / \mathrm{Zn}$-superoxide dismutase (r-hSOD; Pharmacia Chiron, batch no: 1208707 ) received $8 \mathrm{mg} / \mathrm{kg}$ dissolved in 5 $\mathrm{ml}$ of saline, which represents an endotoxin load of $1.3 \mathrm{EU} / \mathrm{kg}$ body weight. Sheep treated with Sigma's SOD, which was derived from bovine erythrocytes (bSOD), received $8 \mathrm{mg} / \mathrm{kg}$ of No. S-2515, Lot 17F-9305 bSOD dissolved in $6 \mathrm{ml}$ saline. This preparation was found to contain an endotoxin contamination of $11 \mathrm{EU} / \mathrm{mg}$, thus giving the animals an endotoxin load of 88 EU $/ \mathrm{kg}$. In addition a group of ewes was treated with a bSOD preparation from Grü- 
nenthal which contained $40 \mathrm{EU} / \mathrm{mg}$ protein (Batch no: JO56). Each ewe was given a dose of $8 \mathrm{mg} / \mathrm{kg}$ diluted in $4 \mathrm{ml}$ of saline, thus $320 \mathrm{EU} / \mathrm{kg}$.

Animals treated solely with endotoxin received a preparation of Salmonella typhimurium ( $1 \mathrm{ng}$ endotoxin $\approx 10 \mathrm{EU}$ in the LAL-test) (see Fredriksson (1984) for a description). The animals received various doses of endotoxin between 1 to $1000 \mathrm{ng} / \mathrm{kg}$ (see Table 1).

Another group of animals received a combination of the above $\mathrm{r}-\mathrm{hSOD}(8 \mathrm{mg} / \mathrm{kg})$ plus $200 \mathrm{ng} / \mathrm{kg}$ endotoxin. These substances were mixed together before injection.

Blood was collected into 2 Vacutainer tubes ( 1 with EDTA and 1 with heparin) according to the following time schedules: 1) in the first 2 trials: $-1,0,1,2,3,4,5,6,7,8,9,10$, $24 \mathrm{~h}$, and 2) in the subsequent trials: -60 , $-40,-20,0,20,40,60,80,100,120,140$, $160,180,240,300,360 \mathrm{~min}$. The EDTAtreated blood was used to determine total white blood cell (WBC) numbers and to do a differential cell count. This count was simplified so that all neutrophils, eosinophils and basophils were grouped together as polymorphonucleocytes (PMN) and monocytes and macrophages as monocytes (M). White blood cells were counted using an AJ134 cell counter. The heparinized blood was centrifuged and pipetted off for later 15-keto-(13,14)-dihydro-PGF $2 a$ analysis according to the method described by Granström \& Kindahl (1982).

Rectal body temperature was recorded using an electronic thermometer (Terumo). All possible efforts were made to obtain accurate temperature readings: the probe was inserted approximately $8 \mathrm{~cm}$ into the rectum and moved around slightly to try to avoid measurement of fecal mass temperature instead of body temperature. Temperature was taken simultaneously with blood collection.
Table 1. Experimental design of study.

\begin{tabular}{lc}
\hline Treatment & $\begin{array}{c}\text { No. of } \\
\text { treatments }\end{array}$ \\
\hline Control & 4 \\
Pharmacia-Chiron r-hSOD $(8 \mathrm{mg} / \mathrm{kg})$ & 3 \\
Sigma bSOD $(8 \mathrm{mg} / \mathrm{kg})$ & 2 \\
Grünenthal bSOD $(8 \mathrm{mg} / \mathrm{kg})$ & 3 \\
Pharmacia-Chiron r-hSOD $(8 \mathrm{mg} / \mathrm{kg})$ & \\
$\quad+$ LPS $(200 \mathrm{ng} / \mathrm{kg})$ & 2 \\
LPS (1000 ng/kg) & 2 \\
LPS (200 ng/kg) & 2 \\
LPS (100 ng/kg) & 2 \\
LPS (50 ng/kg) & 2 \\
LPS (20 ng/kg) & 2 \\
Low dose group: & \\
$\quad$ LPS (10 ng/kg) & 2 \\
$\quad$ LPS $(5 \mathrm{ng} / \mathrm{kg})$ & 2 \\
$\quad$ LPS $(1 \mathrm{ng} / \mathrm{kg})$ & 1 \\
\hline
\end{tabular}

Note that although care was taken to avoid stressing the animals unduly, the ewes were especially excited during the first blood collections when they were most unused to being handled.

\section{Results \\ Control and superoxide dismutase treated animals}

The sheep in the control group exhibited a slight decrease in body temperature during the experimental period (Fig. 1A). There was no net change in the concentration of the main metabolite of prostaglandin $F_{2 a}$, 15-ketodihydro-PGF $2 a$, in the peripheral venous blood. Concentration was however not totally constant, but varied slightly over time (Fig. 1A). There were for example slight increases in the concentration at approximately 1 and $5 \mathrm{~h}$ after saline administration. Note that these increases were also seen in other groups, albeit to different degrees (see Figs. 1B, 1C, and 1D). The population of circulating white blood cells was also fairly constant in the control group (Fig. 

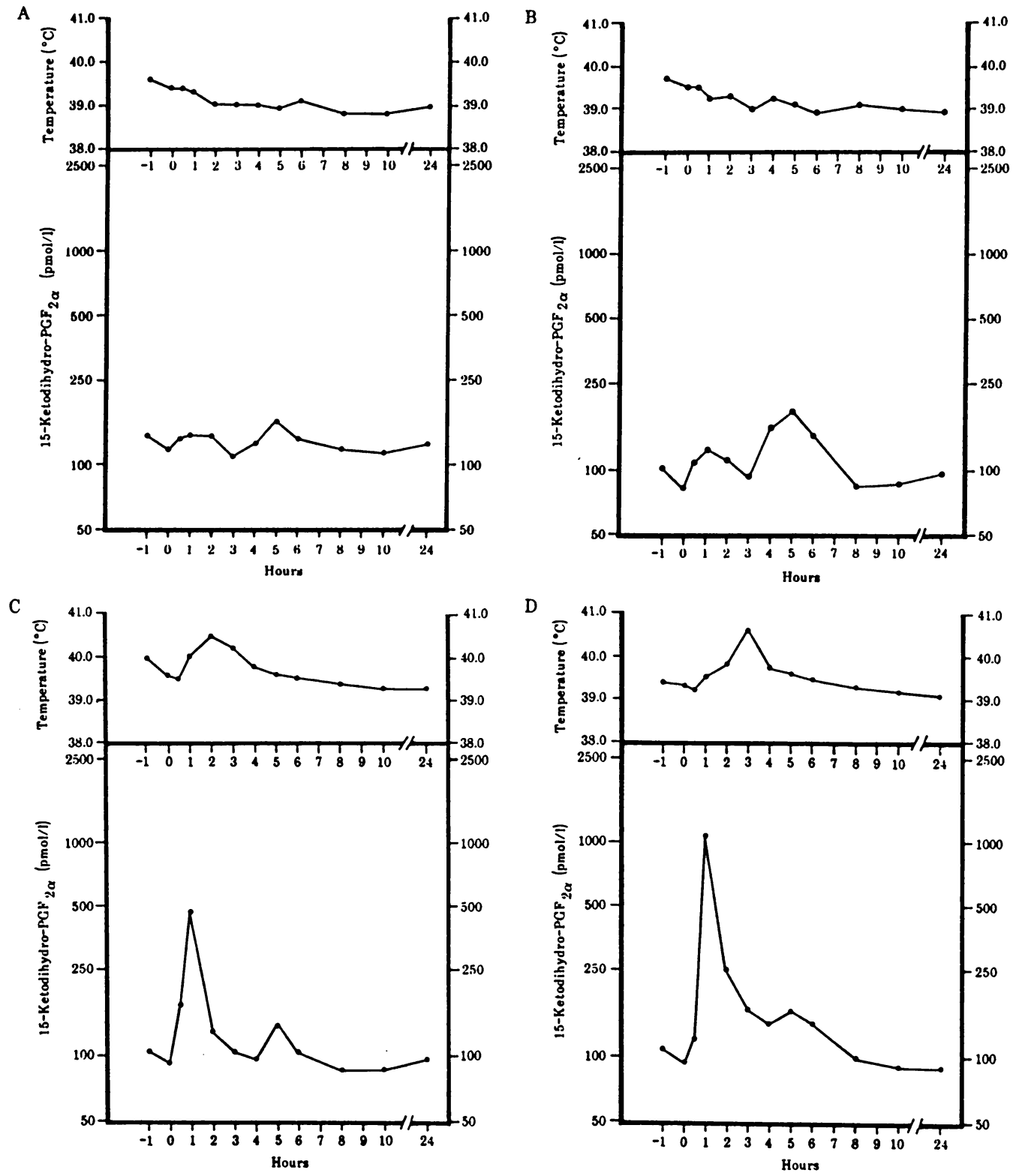

Figure 1. Changes in body temperature and concentration of 15 -keto-(13,14)-dihydro-PGF $2 \alpha$ in peripheral venous blood of ewes treated with either $5 \mathrm{ml}$ of saline (A), or $8 \mathrm{mg} / \mathrm{kg}$ of Pharmacia-Chiron's r-hSOD (B), Grünenthal's bSOD (C), or Sigma's bSOD (D). (All treatments administered i.v. shortly after time $0 \mathrm{~h}$ ). 
A

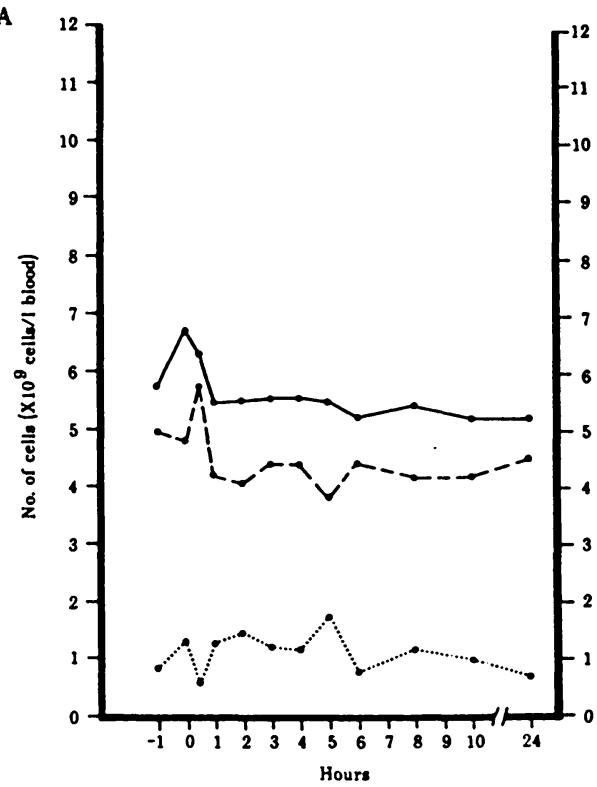

C

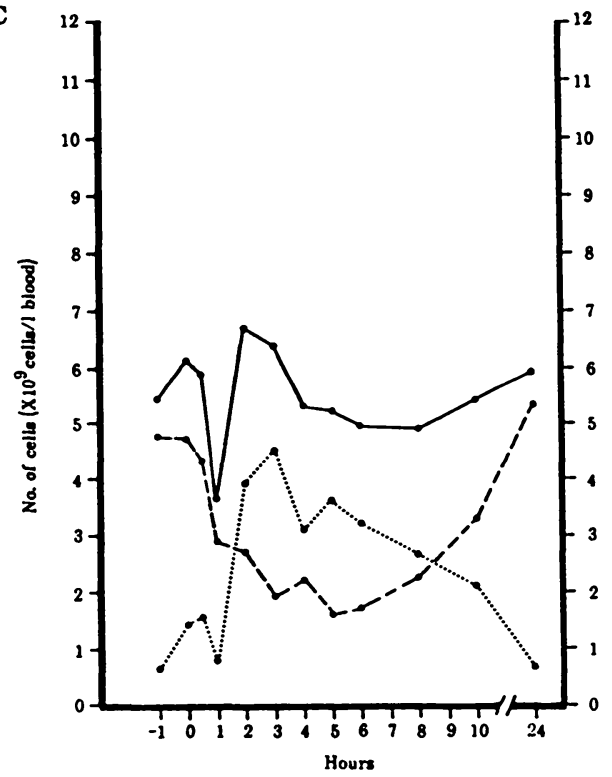

B

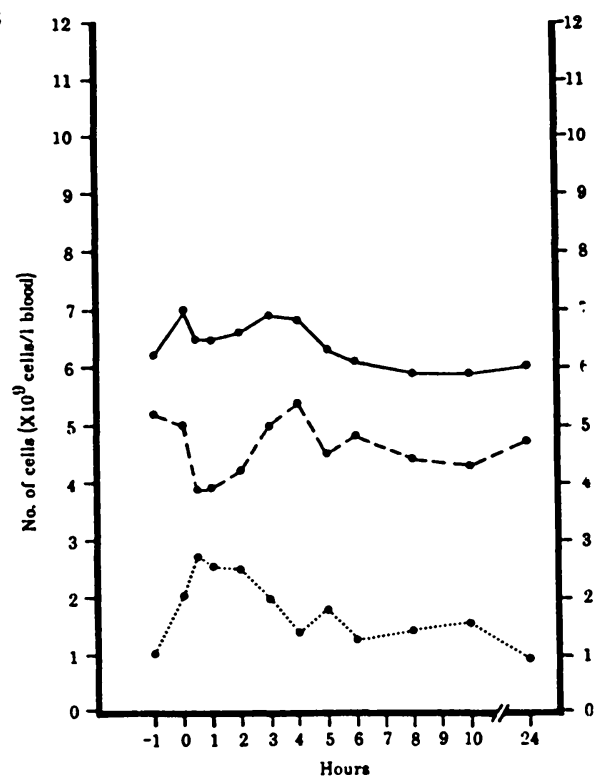

D

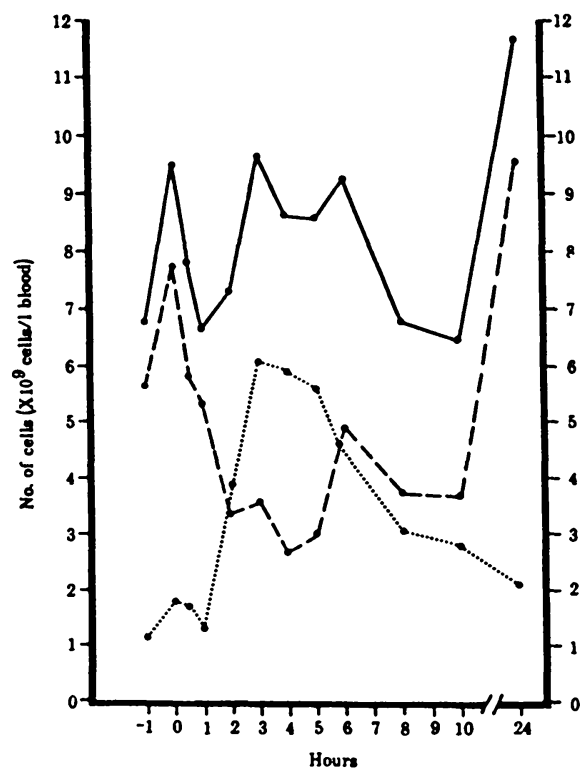

Figure 2. Changes in the total number of leukocytes and monocytes $(---0)$ circulating in the peripheral venous blood in ewes treated with either $5 \mathrm{ml}$ of saline (A), or $8 \mathrm{mg} / \mathrm{kg}$ of Pharmacia-Chiron's r-hSOD (B), Grünenthal's bSOD (C), or Sigma's bSOD (D). (All treatments administered i.v. shortly after time $0 \mathrm{~h}$ ). 
A

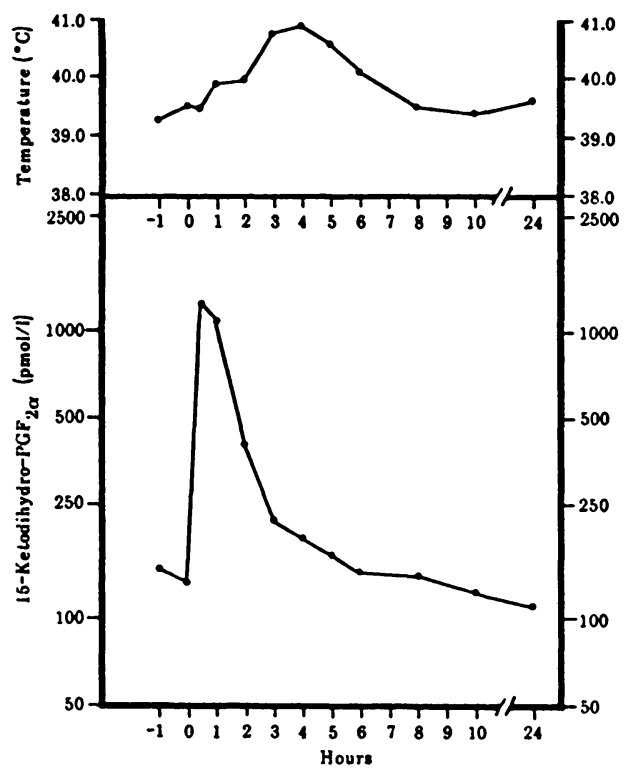

B

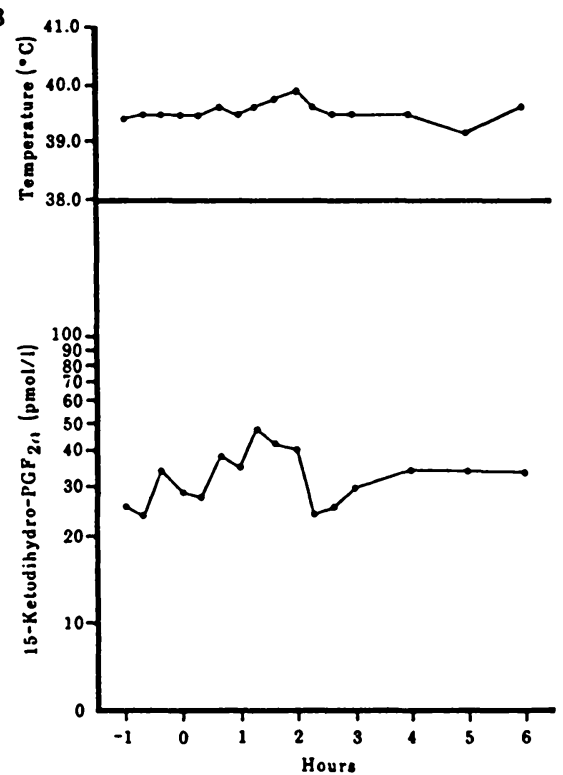

Figure 3. Changes in body temperature and concentration of 15 -keto-(13,14)-dihydro- $\mathrm{PGF}_{2 \alpha}$ in peripheral venous blood in ewes which received a high dose $(200 \mathrm{ng} / \mathrm{kg})(\mathrm{A})$, or a low dose $(10,5$, or $1 \mathrm{ng} / \mathrm{kg})(\mathrm{B})$

Salmonella typhimurium endotoxin. (All treatments administered i.v. shortly after time $0 \mathrm{~h}$ ).

$2 A$ ), with no major changes in either the total number or the relative numbers of PMN and $M$ cells.

The biological response of animals treated with r-hSOD was quite similar to that of the control group (Figs. 1B and 2B). This group had, however, more exaggerated increases in 15-ketodihydro- PGF $_{2 a}$ concentration at 1 and $5 \mathrm{~h}$ after treatment administration (Fig. 1B). In addition, although the total number of leukocytes was fairly constant overall, there was a trend to a decrease in the number of $M$ and an increase in PMN for $4 \mathrm{~h}$ after treatment administration (Fig. 2B).

Both groups of animals treated with the bSOD preparations (Grünenthal and Sigma), which were substantially contaminated with endotoxin, reacted with pronounced changes in the biological parameters studied (Figs. IC \& D and 2C \& D). Animals which re- ceived bSOD had increases in body temperature from 1 to $5 \mathrm{~h}$ after the administration. The peaks in the concentration of 15ketodihydro-PGF ${ }_{2 a}$ were both greater and more distinct at time 1 and $5 \mathrm{~h}$ than in the control and r-hSOD groups. Animals receiving Sigma's bSOD exhibited by far the largest increase in metabolite concentrations (Fig. 1D). The leukocyte population did not present as clear a picture as did the body temperature and prostaglandin $\mathrm{F}_{2 \alpha}$ metabolite levels (Figs. 2C and 2D). In both groups, however, PMN numbers increased while $\mathrm{M}$ numbers decreased. Animals treated with Sigma's bSOD differed from all the other groups in that $M$ increased greatly $24 \mathrm{~h}$ after treatment administration, which caused a concurrent increase in the total number of circulating leukocytes (Fig. 2D). 

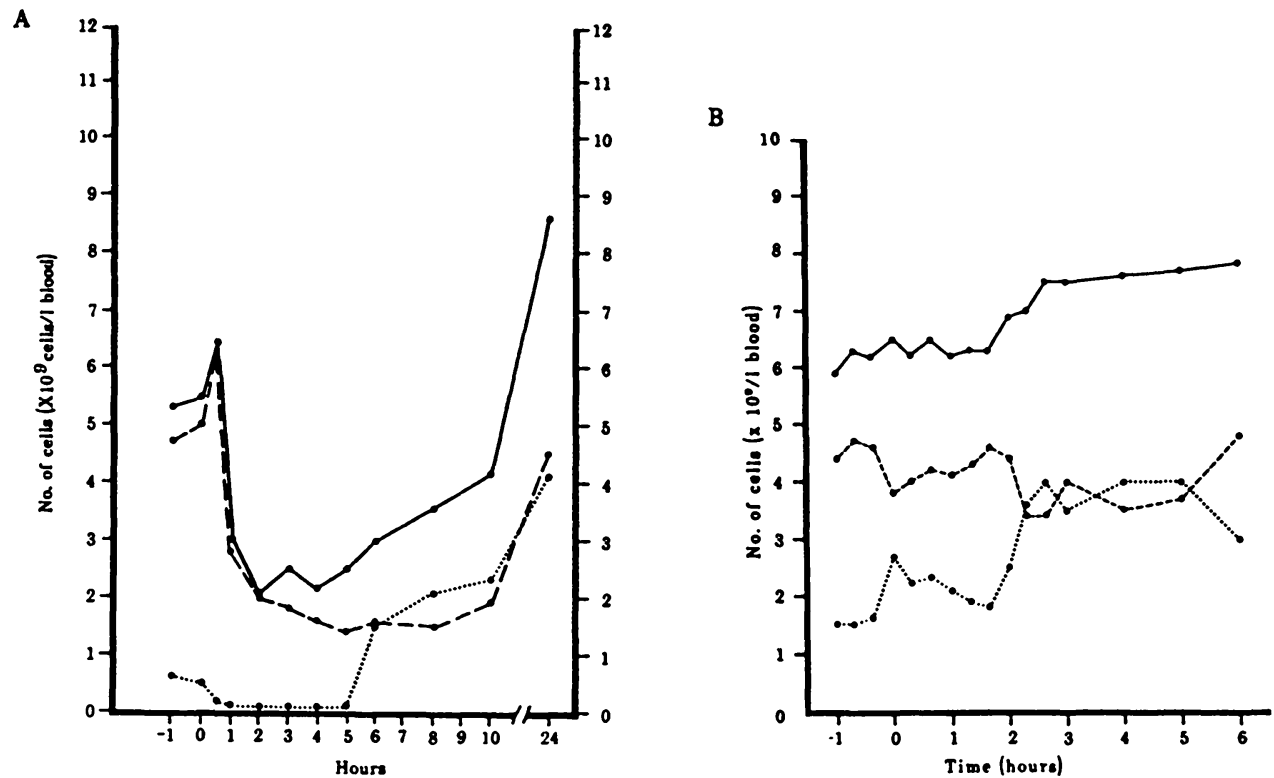

Figure 4. Changes in the total number of leukocytes $(\longrightarrow)$, polymorphonucleocytes $(\bullet \ldots . . \bullet)$, and monocytes (-- $-\bullet)$ circulating in the peripheral venous blood in ewes which received a high dose $(200 \mathrm{ng} / \mathrm{kg})(\mathrm{A})$, or a low dose $(10,5$, or $1 \mathrm{ng} / \mathrm{kg})(\mathrm{B})$, of Salmonella typhimurium endotoxin. (All treatments administered i.v. shortly after time $0 \mathrm{~h}$ ).

\section{Endotoxin treated animals}

Endotoxin was injected on 15 different occasions in a variety of different doses. The biological response to 2 of these doses is shown: $200 \mathrm{ng} / \mathrm{kg}$ (Figs. 3A and 4A), and the low dose group, which included 10,5, and 1 $\mathrm{ng} / \mathrm{kg}$ (Figs. 3B and 4B). These groups were chosen to illustrate how the animals reacted to high versus low doses of endotoxin.

All animals which received doses of endotoxin from 50 to $200 \mathrm{ng} / \mathrm{kg}$ responded with an increase in body temperature (increased 0.5 to $2.0{ }^{\circ} \mathrm{C}$ ), peaks in 15 -ketodihydroPGF $_{2 \alpha}$ which were maximum $1 \mathrm{~h}$ postendotoxin injection (peaks of between 951 to $1683 \mathrm{pmol} / \mathrm{l}$ plasma) (c.f. Fig. 3A), and leukopenia (a net decrease of between 3.6 to 4.5 $\times 10^{9}$ cells/ 1 blood) due mainly to a decrease in $M$ (c.f. Fig. 4A). The larger the endotoxin dose (from between 50 to $200 \mathrm{ng} / \mathrm{kg}$ ), the greater was the increase in temperature and prostaglandin concentration, and the decrease in leukocyte number. Animals treated with $1000 \mathrm{ng} / \mathrm{kg}$ however showed a decrease in body temperature $\left(1.5^{\circ} \mathrm{C}\right)$ combined with a large peak in prostaglandin metabolite levels (peaked at $2140 \mathrm{pmol} / \mathrm{l}$ plasma) and a pronounced decrease in circulating white blood cells (decreased $7.2 \times 10^{9}$ cells/l blood).

Endotoxin administered at $20 \mathrm{ng} / \mathrm{kg}$ evoked both an increase in body temperature $\left(0.5-1.0{ }^{\circ} \mathrm{C}\right)$ and in 15-ketodihydro-PGF $2 a$. Responses of the white blood cell population differed however between the 2 animals, with one animal reacting with a strong leukocytosis while the other animal reacted with a leukopenia.

Endotoxin did not cause any larger changes in temperature when administered at doses less than or equal to $20 \mathrm{ng} / \mathrm{kg}$, although a 
slight increase in body temperature $2 \mathrm{~h}$ after endotoxin administration did occur (Fig. 3B). No clear peak in 15-ketodihydro- PGF $_{2 \alpha}$ was observed at these lower doses, and animals responded to the endotoxin with a leukocytosis rather than a leukopenia (Figs. 3B and 4B). This leukocytosis was brought about by an increase in the number of PMN which occurred from 2 to $5 \mathrm{~h}$ after endotoxin administration (Fig. 4B).

Animals which received $200 \mathrm{ng} / \mathrm{kg}$ endotoxin mixed with Pharmacia-Chiron's r-hSOD reacted in a similar manner to those animals which received $200 \mathrm{ng} / \mathrm{kg}$ endotoxin alone.

\section{Discussion}

In this study it was found that sheep treated with r-hSOD did not differ greatly from the control group in either body temperature or the total number of leukocytes circulating in the peripheral blood. Two changes were however noted; the population of leukocytes shifted to a preponderence of polymorphonucleocyte cells, and the prostaglandin $F_{2 a}$ metabolite exhibited exaggerated peaks as compared to the control group. These findings indicate that even a prepatation that is virtually endotoxin-free $(0.16 \mathrm{EU} / \mathrm{mg}$ protein), can evoke a slight biological response.

Sheep which received more heavily endotoxin-contaminated biological preparations reacted with a number of symptoms classically seen in cases of endotoxemia, that is, a rise in body temperature, a peak in the prostaglandin $F_{2 a}$ metabolite, and a marked shift in the leukocyte population resulting in an increased ratio in PMN/M. It is interesting to note that the degree of biological response did not always parallel the number of endotoxin units administered (as calculated by the LAL test). For example, the animals which received Sigma's bSOD $(=88 \mathrm{EU} / \mathrm{kg})$ responded with the most distinct signs of endotoxemia, despite the fact that the animals treated with Grünenthal's bSOD (= $320 \mathrm{EU} / \mathrm{kg}$ ) actually received more endotoxin units per kilogram body weight. The contaminating endotoxins in the 2 preparations are however of environmental origin and from different sources and may therefore exhibit a different pattern in biological activity as compared to the LAL test. This is an important finding because it indicates that even preparations which are considered to be low in endotoxin contamination by the LAL test may evoke a biological response. Furthermore, as demonstrated by the present findings, animals may actually have changes in prostaglandin metabolites and leukocyte population without a rise in body temperature, and therefore it is even possible that such preparations could pass the in vivo pyrogen test which is routinely done in rabbits (e.g. according to the US Pharmacopeia XXI) despite the fact that they do indeed have biological potency. Animals treated with the highest dose of endotoxin $(1000 \mathrm{ng} / \mathrm{kg})$ had as a matter of fact decreases in body temperatute (see below).

Sheep which received doses of endotoxin greater than or equal to $50 \mathrm{ng} / \mathrm{kg}$ always responded with fever, peaks in 15-ketodihydro-PGF $2 \alpha$, and a severe leukopenia, brought about mainly by a decrease in the number of monocytes. The finding of leukopenia is well documented (Fredriksson 1984). In a similar experiment in rabbits as an animal model, however, the leukopenia induced by endotoxin administration occurred rather by a marked decrease in the number of PMN (Yagoda et al. 1990). One explanation for the different response between these species might be that the sheep has proportionally more $\mathrm{M}$ (and fewer PMN) normally circulating in peripheral venous blood than does the rabbit.

Animals which were treated with 1000 
$\mathrm{ng} / \mathrm{kg}$ endotoxin had similar, albeit greater, prostaglandin and leukocyte responses. Rectal temperature however decreased rather than increased. This phenomenon has also been seen in cows treated with high doses of endotoxins (Fredriksson 1984). This effect is likely explained by the fact that the animals were so clinically affected by the endotoxin that they entered some sort of endotoxin shock resulting in a decreased peripheral blood circulation and thereby a drop in rectal temperature.

A dose of $20 \mathrm{ng} / \mathrm{kg}$ endotoxin appeared to represent the threshold under which animals may respond with leukocytosis (and an increase in the PMN:M ratio) and over which they may respond with leukopenia (due to decreases in both PMN and M). Thus, the animal which exhibited a leukocytosis was more likely less sensitive to this particular endotoxin than was the animal which suffered a leukopenia. A similar threshold effect was also seen in the above mentioned experiment conducted in rabbits (Yagoda et al. 1990).

Animals receiving very low doses of endotoxin, such as those which are found in many biological preparations, also react in a definable manner. Gordon et al. (1987) noted that endotoxin can exert protective effects against inflammation when present at doses as low as $1 \mathrm{ng} / \mathrm{kg}$ in the guinea pig. The present study indicates that sheep are also sensitive enough to show a biological response to such low doses. Doses of endotoxin less than or equal to $10 \mathrm{ng} / \mathrm{kg}$ evoke multiple small peaks in 15-ketodihydro$\mathrm{PGF}_{2 \alpha}$ combined with a leukocytosis. These symptoms are sometimes coupled to a rise in body temperature, but sometimes not; thus it is difficult to judge clinically if the animal has received endotoxin. This problem is of course exacerbated if the animal is anaesthetized because in such case it is impossible to monitor the clinical signs of endotoxemia.

In this experiment r-hSOD was not found to provide any protective effect against endotoxin, as the animals treated with $200 \mathrm{ng} / \mathrm{kg}$ endotoxin mixed with r-hSOD reacted similarly to those which received the same dose of endotoxin alone. Furthermore, r-hSOD did not appear to mask or diminish the biological effects of endotoxin, as might be expected to occur via binding of the endotoxin to proteins in the r-hSOD preparation.

For the purpose of this study, superoxide dismutase was chosen as one example of a pharmaceutical preparation of biological origin, and as such subjected to the risk of endotoxin contamination. The pharmacological effects of superoxide dismutase, as a free radical scavenger, have been extensively studied in recent years (Jolly et al. 1984, Hansson et al. 1986, Uraizee et al. 1987 and Granger 1988). Most of these studies have concerned the protective effects of superoxide dismutase in experimental models where various organs are exposed to ischemia followed by reperfusion. The fact that many of these studies have been performed with enzyme preparations with a substantial degree of endotoxin contamination, gives rise to second thoughts about their conclusions. The mechanism behind ischemia-reperfusion damage is considered to be an acute inflammatory reaction involving the arachidonic acid metabolism as well as inflammatory cells (Mullane et al. 1987, Simpson et al. 1987). Interaction by endotoxins which affect the same biological systems will seriously complicate the conclusions from studies of the efficacy of superoxide dismutase. As already pointed out in the introduction, endotoxins exert a protective effect in acute inflammation (Gordon et al. 1987, Brown et al. 1989). The results obtained here, demonstrating profound biolo- 
gical effects of endotoxins even in low concentrations, further stresses the serious aspects of this problem, which have largely been overlooked in the past. We therefore want to point out this problem to the researchers in the field and also suggest that endotoxin contamination might well be a factor that have contributed to the variability in the outcome of studies focussed on the protective effect of superoxide dismutase.

In conclusion, the present findings demonstrate that endotoxins contaminating biological preparations, also in very low amounts, can have profound biological effects. This provides a serious problem in efficacy studies of pharmaceutical preparations.

\section{Acknowledgements}

This study has been supported by grants from the Swedish Council for Forestry and Agricultural Research and Pharmacia LEO AB.

\section{References}

Asplund Peiró S, Kulander L, Eriksson Ö: Quantitative determination of endotoxins in industrially sterilised medical devices for single use.

J. Hosp. Infect. 1989 (submitted for publication).

Bito $L Z$ : Inflammatory effects of endotoxin-like contaminants in commonly used protein preparations. Science 1977, 196, 83-85.

Brown JM, Grosso MA, Terada LS, Whitman $G J R$, Banerjee $A$, White $C W$, Harken $A H$, Repine $J E$ : Endotoxin pretreatment increases endogenous myocardial catalase activity and decreases ischemia-reperfusion injury of isolated rat hearts. Proc. Natl. Acad. Sci. USA 1989, 86, 2516-2520.

Elin RJ, Wolff SM, McAdam KPWJ, Chedid L, Audibert L, Bernard C, Oberling F: Properties of reference Escherichia coli endotoxin and its phthalylated derivative in humans. J. inf. Dis. 1981, 144, 329-336.

Fredriksson $G$ : Some reproductive and clinical aspects of endotoxins in cows with special emphasis on the role of prostaglandins. Acta vet. scand. 1984, 25, 365-373.

Friberger $P$ : The design of a reliable endotoxin test. In: Bacterial endotoxins: Structure, biomedical significance, and detection with the Limulus Amoebocyte Lysate test. Eds. ten Cates JW, Büller H, Stark A and Levine Y. Alan R Liss Inc., NY, 1985, 139-149.

Gordon T, Milligan SA, Levin J, Thompson JE, Fine JM, Sheppard D: Apparent effect of catalase on airway edema in guinea pigs - Role of endotoxin contamination. Amer. Rev. respir. Dis. 1987, 135, 854-859.

Granger N: Role of xanthine oxidase and granulocytes in ischemic-reperfusion injury. Amer. J. Physiol. 1988, 255, H1269-H1275.

Granström E, Kindahl H: Radioimmunoassay of the major plasma metabolite of $\mathrm{PGF}_{2 a}, 15-$ keto-13,14-dihydro-PGF $2 \alpha$. Methods Enzymol. 1982, 86, 320-339.

Hansson $R$, Johansson $S$, Jonsson $O$, Pettersson $S$, Schertstén $T$, Waldenström J: Kidney protection by pretreatment with free radical scavengers and allopurinol: Renal function at recirculation after warm ischemia in rabbits. Clin. Sci. 1986, 71, 245-251.

Jolly SR, Kane WJ, Sailie MB, Abrams GD, Lucchesi $B R$ : Canine myocardial reperfusion injury. Its reduction by the combined administration of superoxide dismutase and catalase. Circ. Res. 1984, 54, 277-285.

Kindahl H, Odensvik $K$, Fredriksson $G$, Cort $N$, Daels $P$, Hughes J, Stabenfeldt G: Effects of endotoxins on prostaglandin biosynthesis and reproductive function in farm animals. Proc. $4^{\text {th }}$ Congress of European Association for Veterinary Pharmacology \& Toxicology, Budapest, Aug. 28-Sept. 2, 1988.

Kure R, Grendahl H, Paulssen J: Pyrogens from surgeon's sterile latex gloves. Acta Path. Microbiol. Immunol. Scand., Section B, 1982, 90, 85-88.

Lindgren $S$, Bromander A, Pettersson K: Evaluation of silage additives using scale-model silos. Swedish J. Agric. Res. 1988, 18, 41-49.

Luthman J, Kindahl H, Jacobsson SO, Thunberg $L$ : Local and general effects of Salmonella 
typhimurium endotoxin in calves. J. Vet. Med. A. $1988,35,586-595$.

Morrison DC, Raziuddin S: Lipopolysaccharides and endotoxin. In Immunopharmacology. Eds. Sirois $\mathbf{P}$ and Rola-Pleszcynski M. Elsevier Biomed. Press 1982, 169-199.

Mullane KM, Salmon JA, Kraemer R: Leukocyte derived metabolites of arachidonic acid in ischemia-induced myocardial injury. Fed. Proc. 1987, 46, 2422-2433.

Simpson PJ, Mickelson JK, Lucchesi BR: Free radical scavengers in myocardial ischemia. Fed. Proc. 1987, 46, 2413-2421.

Uraizee A, Reimer KA, Murry CE, Jennings RB: Failure of superoxide dismutase to limit size of myocardial infarction after 40 minutes of ischemia and 4 days of reperfusion in dogs. Circulation 1987, 75, 1237-1248.

Yagoda $C$, Bylund-Fellenius $A C$, Kindahl $H$ : Some effects of Gram-negative bacterial endotoxin and its importance as a contaminator of biological preparations. Acta vet. scand. 1990, 31, 193-206.

Zuckerman KS, Quesenberry PJ, Levin J, Sullivan $R$ : Contamination of erythropoietin by endotoxin. In vivo and in vitro effects on murine erythropoiesis. Blood 1979, 54, 146-158.

\section{Sammanfattning \\ Biologiska svaret mot endotoxin-kontaminerade superoxid-dismutaspreparationer och endotoxin hos fär. \\ Syftet med denna studie är att bedöma det biologi- ska svaret hos får till olika doser av endotoxin och några endotoxin-kontaminerade enzympreparatio- ner. Enzymet som användes i detta försök var superoxid-dismutas (SOD), eftersom det studeras i många olika försök och några preparationer upp- täcktes vara svårt kontaminerade av endotoxiner. En grupp av tackor injicerades intravenöst med några olika behandlingar. Perifert blod användes för att räkna det totala antalet leukocyter, göra en}

differentialräkning för att skilja polymorfonukleocyter (PMN) från monocyter (M), och mäta koncentrationen av 15-ketodihydro- $\mathrm{PGF}_{2 \alpha}$. Vidare, uppmättes rektaltemperaturen. Behandlingar inkluderade koksalt (kontroll), Pharmacia-Chiron's $\mathrm{Cu} / \mathrm{Zn}$-SOD (r-hSOD, $8 \mathrm{mg} / \mathrm{kg}$ ), Sigma's bovina SOD (bSOD, $8 \mathrm{mg} / \mathrm{kg}$ ), Grünenthal's bSOD (8 $\mathrm{mg} / \mathrm{kg}$ ), olika doser av Salmonella typhimurium endotoxin $(1000,200,100,50,20,10,5$, och 1 $\mathrm{ng} / \mathrm{kg})$, och en blandning av endotoxin $(200 \mathrm{ng} / \mathrm{kg})$ plus $\mathrm{r}-\mathrm{hSOD}(8 \mathrm{mg} / \mathrm{kg})$.

Resultaten visar att făr reagerar mot endotoxinkontaminerade SOD preparationer med en endotoxemi som liknar den som finns hos djur som har fătt rent endotoxin. Denna endotoxemi inkluderar, bl. a., en ökning i rektaltemperatur, en topp i $\mathrm{PGF}_{2 \alpha}$ metaboliten, och en ökning i PMN/M kvot.

Endotoxin administrerat i doser mellan 50 till 200 $\mathrm{ng} / \mathrm{kg}$ framkallade också den förväntade bilden på endotoxemi. Emellertid, ledde en dos av 1000 $\mathrm{ng} / \mathrm{kg}$ endotoxin till en sänkning av rektaltemperaturen. Detta kan bero på att djuren har kommit i ett endotoxemisk chocktillstånd, och därför har den perifera blodcirkulation minskat.

Lägre doser av endotoxin $(10,5$, och $1 \mathrm{ng} / \mathrm{kg})$ orsakar en leukocytos på grund av en ökning i $\mathrm{PMN}$; det var ingen markant förändring i rektaltemperatur eller i 15 -ketodihydro-PGF $2 a$ koncentrationen. Endotoxemi som framkallades av blandningen av r-hSOD med $200 \mathrm{ng} / \mathrm{kg}$ endotoxin liknade den som orsakades av samma dos av endast endotoxin.

Sammanfattningsvis, om en endotoxin-kontaminerad enzympreparation användes i en farmakologisk studie skulle det sannolikt producera missvisande resultat. Det skulle vara svårt att skilja effekterna av endotoxinet från de av preparationen själv. Därför är det viktigt att forskarna är medvetna om möjligheten att preparationerna som användes $i$ försök kan vara kontaminerad av endotoxiner.

(Received September 11, 1989; accepted September 27, 1989).

Reprints may be requested from: Hans Kindahl, Department of Obstetrics and Gynaecology, Swedish University of Agricultural Sciences, Box 7039, S-750 07 Uppsala, Sweden. 